\title{
Earnings Management Effect In Different Stock Market Cycles
}

\author{
Alireza Daneshfar, Ph.D., University of New Haven, USA \\ Daniel Zeghal, Ph.D., University of Ottawa, Canada \\ Mohammad J. Saei, M.S., Ferdosi University of Mashad, Iran
}

\begin{abstract}
This study examines the association between stock prices and discretionary accruals in different stock market cycles. The study presents evidence for a discrepancy in prior research and shows that investors are able to identify earnings management only in some cases. We argue that investors' reaction to the true nature of EPS varies in different market cycles. We suggests that investors pay less attention to the nature of EPS changes in an optimistic cycles, and are more critical in neutral or pessimistic cycles. Therefore, investors are more likely to detect and count for any earnings management in the neutral or pessimistic cycle than in the optimistic cycle. The test results indicated that the association between discretionary accruals and abnormal stock returns were insignificant in the neutral market cycle, significant and positive in the optimistic cycle and significant and negative in the pessimistic cycle. These findings indicate that investors tend to ignore the income-increasing effect of discretionary accruals on EPS changes in an optimistic market. The findings suggest that researchers investigating the association between stock prices and earnings management should control for the type of the market cycle from which their samples are drawn.
\end{abstract}

\section{INTRODUCTION}

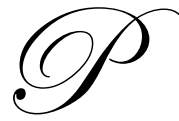

rior research on the ability of earnings management to push up stock prices in different market situations has brought conflicting results. Some studies have found that earnings management can push up stock prices (e.g.Yongtae and Myung, 2005; Fischer and Stocken, 2004; Abarbanell and Lehavy, 2003). Other studies have found that investors were able to find the true nature of changes in earnings per share (EPS) and disregarded the effect of opportunistic earnings management on the stock prices (e.g. Siew, Welch and Wong, 1998; Rangan, 1998; Marquardt and Wiedman, 2004; Aharony, Lee and Wong, 2000). The interesting question that emerges is why investors were able to identify the earnings management in some, but not in other, cases. This study addresses this issue by investigating the effect of stock market cycles on investors' use of EPS information. As earnings management often take place through the inflation of discretionary accruals, we investigate whether different market cycles affect investors' reaction to discretionary accruals. We classify market cycles as optimistic, neutral and pessimistic. Optimistic market cycle is referred to the situation in which stock prices are increasing, and investors are optimistic about future economy. Neutral market cycle refers to the situation when the market environment does not bring any emotions, and investors evaluate the economic information including EPS changes analytically. Pessimistic market cycle exists when a price reevaluation begins across the board and current prices are seen as too overstated. In this situation market goes through price correction and the corporate and national economic fundamentals do not support the current prices. Investors become critic about the management actions and evaluate the information about companies and the economy critically.

Investors are more likely to pay less attention to the true nature of earnings changes in an optimistic market cycle because in the optimistic market cycle they are not concerned about management actions and its ambitious business plans due to receiving positive information about increases in EPS. This situation presents an opportunity for the earnings management through discretionary accruals. The positive market trend in an optimistic cycle attracts more unsophisticated and inexperienced investors, who are likely to fail to understand the true nature of changes in EPS. This study contributes to the literature on the subject by improving the understanding of when investors are 
likely to identify the managed earnings and when they are less likely to do so. Findings of this study should help future researchers as well as financial analysts to improve their analysis of stock prices and earning management through showing the effect market cycles have on investors' use of EPS information.

This paper is organized as follows: section two presents literature review and hypothesis development; section three describes methodology; section four presents test results followed by the summary and discussion in section five.

\section{LITERATURE REVIEW AND HYPOTHESIS DEVELOPMENT}

Prior studies present evidence of opportunistic earnings manipulation in various situations. Many research investigated the earnings manipulation in the case of equity offering. These studies documented that firms used income-increasing accruals before a seasoned equity offering to inflate earnings numbers (e.g Teoh et al., 1998; Rangan 1998; Shivakumar, 2000; Marquardt and Wiedman, 2004; Yongtae and Myung, 2005). Similar pattern was found for the case of initial public offering firms (e.g. Li and McConomy, 2004; Ducharme, Malatesta and Sefcik, 2004) and for the case of stock financial acquisitions (e.g. Erickson and Wang, 1998; Louis, 2004; Heron and Lie, 2002).

Another line of research investigated earnings manipulation in the cases of meeting forecasts done by financial analysts. These studies found that management engaged in earnings manipulation to meet the expectations and avoid reporting earnings lower than analysts' forecasts (e.g. Burgstahler and Eames, 1998; Cheng and Warfield, 2005, Lacina and Karim, 2004). Similar findings were reported in research by Abarbanell and Lehavy (2003), which found that firms receiving buy recommendations from analysts are more likely to manage their earnings to meet analysts' earnings expectations. Prior studies also presented evidence that firms engage in earnings management to avoid reporting EPS lower than management earnings forecasts (e.g. Kasznik, 1999; Karamanou and Vafeas, 2005; Ajinkya, Bhojraj and Sengupta, 2005). Burgstahler and Dichev (1997) found that firms manage their reported earnings to avoid earnings decreases and losses. They also found that there are unusually low frequencies of small decreases in earnings and small losses, and unusually higher frequencies of small increases in earnings and small positive income. Degeorge et al. (1999) also found that firms that are falling short of thresholds manage their earnings upward.

While many of prior studies presented useful insight about the situations in which firms are likely to manage their earnings, there are only few studies that addressed the situation in which a firm's ability to engage in earnings management is restricted. Investigation of factors that restrict the management's ability to engage in earnings management is important because it can help in investigating the process of engaging in earnings management by firms (rather than only looking at the evidence of earnings management). For example, Marquardt and Wiedman (2004) found that firms use different accruals to manage their earnings. Also, Barton and Simko (2002) found that due to the effect of accruals reversion, earnings management in the periods following the use of accruals is limited by type and extent of the accruals used in the preceding periods. Detection likelihood is another factor that has been found effective on the ability of management to engage in earnings management. DuCharme at al. (2004) found that the magnitude of unexpected accruals is positively associated with probability of shareholder litigation against stock issuing firms. Beneish (1999) found that increase in total accruals was associated with the probability of being the target of SEC enforcement action. Another factor limiting the likelihood of earnings management investigated by prior studies is perceived earnings quality (Leuz, Nanda and Wysocki, 2003). These research found that undetected earnings management could negatively impact the perceived earnings quality by shareholders if the earnings management results in higher gap between earnings and cash flow. Research investigating when firms are likely and unlikely to engage in earnings management is relatively new, and further studies are needed to explore other factors that may affect the process of engaging in earnings management, however.

The current study contributes to the literature by investigating the effect of stock market cycles on the likelihood of engaging in earnings management. The investigation of the effect of market cycles is important as prior studies found that economic conditions, such as market cycles, affect corporate decisions on executive performance evaluation and their compensation structure (e.g. Matolcsy, 2000). 
Different market cycles could influence the engagement in earnings management by affecting shareholders' emotional reaction to earnings changes. In an optimistic market cycle, investors are less likely to investigate the true nature of changes in earnings, due to an optimistic environment on the market, as well as the existence of naive investors. Naive investors, attracted by the market's high returns, may not be able to investigate the true nature of EPS changes. Thus, the likelihood of detection or questioning the accrual changes is lower in the optimistic cycle. Consequently, the potential cost of earnings management in the optimistic market cycle is lower. In a neutral cycle, however, investors have no emotional reactions to earnings changes. They analyze the management actions analytically, especially for financial reporting policies. There are also fewer naive investors in the market, due to a lack of large stock returns in the short-time, a situation usually observed in an optimistic market cycle. Therefore, in the case of neutral market cycle, investors are likely to detect the managed portion of earnings and discount it in the prices. A pessimistic market cycle affects the cost and likelihood of earnings management differently. In a pessimistic cycle investors are more critical of management actions, especially financial reporting, due to the market environment being pessimistic. In this situation, investors' reaction to earnings management might be negative, meaning that investors may reduce the stock price of the firms that report increases in discretionary accruals. In addition, the impact of negative news in this cycle is greater than the effect of good news.

In accordance with our discussion, we define the following three hypotheses:

H1: In an optimistic market cycle, increase in discretionary accruals is positively associated with increase in unexpected stock returns.

H2: In a neutral market environment, increase in discretionary accruals is not significantly associated with unexpected stock returns.

H3: In a pessimistic market environment, increase in discretionary accruals is associated with a negative unexpected stock returns.

\section{DATA AND METHODOLOGY}

\section{Time period and data}

Table 1

Market Trend During The Period Of January 01, 1999 To March 31, 2000

Panel A: Change in the major indexes during neutral cycle

\begin{tabular}{|c|c|c|c|c|}
\hline Index & July 01,97 & Sep 30,98 & Change & $\%$ of change \\
\hline $\mathrm{DJI}$ & 7722 & 7842 & 120 & $1.5 \%$ \\
\hline NASDAQ & 953 & 1345 & 392 & $41 \%$ \\
\hline S\&P 500 & 891 & 1017 & 126 & $14 \%$ \\
\hline
\end{tabular}

Panel B: Change in the major indexes during optimistic cycle

\begin{tabular}{|c|c|c|c|c|}
\hline$\underline{\text { Index }}$ & $\underline{\text { Oct } 01,98}$ & $\underline{\operatorname{Mar} 31,00}$ & Change & $\%$ of change \\
\hline DJI & 7632 & 10921 & 3289 & $43 \%$ \\
\hline NASDAQ & 1273 & 4572 & 3299 & $259 \%$ \\
\hline S\&P 500 & 986 & 1498 & 512 & $52 \%$ \\
\hline
\end{tabular}

Panel C: Change in the major indexes during pessimistic cycle

\begin{tabular}{|c|c|c|c|c|}
\hline Index & April 03, 00 & June 29, 01 & Change & $\%$ of change \\
\hline$\overline{\mathrm{DJI}}$ & 11221 & 10502 & -719 & $-6.4 \%$ \\
\hline NASDAQ & 4077 & 1832 & -2245 & $-55 \%$ \\
\hline S\&P 500 & 1505 & 1224 & -281 & $-19 \%$ \\
\hline
\end{tabular}


As the optimistic market cycle, the period of the third quarter of 1998 until the end of the first quarter of 2000 was selected. In this period, a major stock market indexes rose significantly as presented in panel B of Table 1. It shows that the market breath was generally positive and stock prices rose across the board during this period. Dow Jones Industrials (DJI) rose 43\%, NASDAQ rose 259\% and S\&P500 rose 52\%.Such optimism, however, did not exist in a cycles preceding and following the discussed period. Five quarters were selected before the optimistic cycle as the neutral market cycle. During this period, DJI rose only $1.5 \%$, NASDAQ rose $41 \%$ and S\&P500 rose $14 \%$. These increase are consistent with normal market returns (Table 1, Panel A). The NASDAQ increase of $41 \%$ is also normal, since the market was hit by a new wave of IPO companies during that period. As the pessimistic cycle, we chose five quarters following the optimistic cycle. During this period, DJI lost 6.4\%, NASAQ lost 55\% and S\&P500 lost 19\% (Table 1, Panel C). The magnetite of the losses indicates that investors became very critic during this period, and price corrections begun to occur across the board. The reason we used quarterly data is because quarterly earnings news has been considered the most important piece of information for stock price evaluation and it allows us to investigate earnings management on a quarterly basis.

\section{Discretionary Accruals}

Firms may manipulate their earnings in two ways. Forstly, it can be done by manipulating a specific items such as accounts receivable (Beneish, 1997), bad-debt expense (McNichols and Wilson, 1988), or loan losses (Beaver and Engel, 1996). Secondly, the manipulation can be done through total accruals which are non-cash items and can have increasing or decreasing effect on net income. While the first approach investigates how a specific accounting item could be used to manipulate earnings, the second approach investigates the collective effect of accrual items on the reported earnings. In this paper, we use the second approach, for our objective is to investigate earnings management in general, without referring to a particular item. Therefore, we calculate total accruals for firm $i$ in quarter $t$ as follows:

$\mathrm{TAC}_{\mathrm{it}}=\left(\Delta \mathrm{CA}_{\mathrm{it}}-\Delta \mathrm{Cash}_{\mathrm{it}}\right)-\left(\Delta \mathrm{CL}_{\mathrm{it}}-\Delta \mathrm{CPL}_{\mathrm{it}}\right)-\mathrm{DEP}_{\mathrm{it}}$

where $\mathrm{TAC}_{\mathrm{it}}$ is total accruals, $\mathrm{CA}_{\mathrm{it}}$ is total current assets, Cash is total cash and equivalent, $\mathrm{CL}_{\mathrm{it}}$ is total current liabilities, $\mathrm{CPL}_{\mathrm{it}}$ is total current portion of long term debt, and $\mathrm{DEP}_{\mathrm{it}}$ is depreciation expense. $\Delta$ indicates change in the respective variable. $\mathrm{TAC}_{\mathrm{it}}$ includes both portions of non-discretionary and discretionary accruals. Accordingly, discretionary accruals are computed as follows:

$\mathrm{DAC}_{\mathrm{it}}=\mathrm{TAC}_{\mathrm{it}}-\mathrm{NDAC}_{\mathrm{it}}$

where $\mathrm{DAC}_{\mathrm{it}}$ is discretionary accruals for firm $\mathrm{i}$ in quarter $\mathrm{t}$ and $\mathrm{TAC}_{\mathrm{it}}$ is total accruals reported by firm $i$ in the same quarter. $\mathrm{NDAC}_{\mathrm{it}}$ refers to non-discretionary accruals.

In the absence of earnings management, the mean of $\mathrm{DAC}_{\mathrm{it}}$ should be zero during the test period. $\mathrm{A}$ positive mean of discretionary accruals indicates the use of accruals to overstate earnings. Non-discretionary accruals are estimated using modified Jones model. This model has been found more appropriate than other existing models in capturing non-discretionary accruals (Dechow et al., 1995). We used this model to estimate nondiscretionary accruals:

$\mathrm{NDAC}_{\mathrm{it}} / \mathrm{TA}_{\mathrm{i}, \mathrm{t}-1}=\beta_{1}\left(1 / \mathrm{TA}_{\mathrm{i}, \mathrm{t}-1}\right)+\beta_{2}\left(\mathrm{NREV}_{\mathrm{i}, \mathrm{t}} / \mathrm{TA}_{\mathrm{it}-1}\right)+\beta_{3}\left(\mathrm{PPE}_{\mathrm{it}} / \mathrm{TA}_{\mathrm{i}, \mathrm{t}-1}\right)$

where $\mathrm{NDAC}_{\mathrm{it}}$ refers to non-discretionary accruals, $\mathrm{TA}_{\mathrm{i}, \mathrm{t}-1}$ is total assets, $\mathrm{NREV}_{\mathrm{i}, \mathrm{t}}$ is total revenue net of receivables, $\mathrm{PPE}_{\mathrm{i}, \mathrm{t}}$ is total plant, property and equipment, and $\beta$ is the respective coefficient. The model parameters, $\beta 1, \beta 2$ and $\beta 3$, are estimated using an OLS regression.

\section{Sample Selection}

Initial samples were obtained from Compustat. We required that firms must have at least 25 necessary data to compute model 3 for the period of the first quarter of 1990 through the end of the third quarter of 1998. This 
selection procedure resulted in a sample of 1509 firms. Table 2 presents the breakdown of the sample based on industry membership. Table 3 provides the descriptive statistics for the sample.

Table 2

Industry Classification Of Sample Firms

\begin{tabular}{|c|c|}
\hline & Number of Firms \\
\hline Basic Industries & 115 \\
\hline Capital Goods & 385 \\
\hline Construction & 44 \\
\hline Consumer Goods & 813 \\
\hline Energy & 110 \\
\hline Finance & 42 \\
\hline Total & $\overline{1509}$ \\
\hline \multicolumn{2}{|c|}{ The following approach is used to classify the samples into the different industries: } \\
\hline Basic Industries: & $1000-1299,1400-1499,2600-2699,2800-2829,2870-2899,3300-3399$. \\
\hline Capital Goods: & $\begin{array}{l}3400-3419,3440-3599,3620-3629,3670-3699,3800-3849,5080-5089,5100-5129, \\
5160-5169,7300-7399 .\end{array}$ \\
\hline Construction: & $1500-1999,2400-2499,3220-3299,3430-3439,5200-5219$. \\
\hline Consumer Goods: & 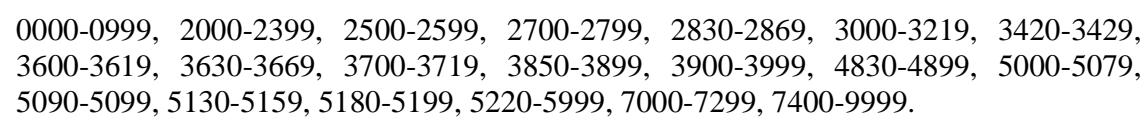 \\
\hline Energy: & 1300-1399, 2900-2999, 5170-5179. \\
\hline Finance: & $6000-6999$. \\
\hline
\end{tabular}

Table 3

Descriptive Statistics

\begin{tabular}{|lcc|}
\hline \multicolumn{3}{c|}{ Descriptive Statistics } \\
\hline \multicolumn{3}{l}{ Panel A: Breakdown of discretionary accruals by period: } \\
Market cycle & $\underline{\text { Mean }}$ & $\underline{\underline{\text { SD }}}$ \\
Neutral & .0202 & 1.212 \\
Optimistic & .0595 & 1.239 \\
Pessimistic & -.0121 & .374 \\
\hline
\end{tabular}

Table 2 shows that the sample is distributed across industries considering the size of each industry. Table 3 shows that the means of discretionary accruals. The negative mean in the pessimistic cycle indicates the mean reversion of accruals.

\section{Hypothesis Testing}

We use the following model to test the hypotheses:

$$
\mathrm{AR}_{\mathrm{it}}=\beta_{0}+\beta_{1} \mathrm{DTAC}_{\mathrm{it}}
$$


where $\mathrm{AR}_{\mathrm{it}}$ is unexpected stock returns and $\mathrm{DTAC} \mathrm{C}_{\mathrm{it}}$ is discretionary accruals. Investors' reaction to charges in discretionary accruals in each market cycle is tested as follows:

If $\beta_{1}=0$ no investors' reaction

If $\beta_{1}>0$ positive reaction

If $\beta_{1}<0$ negative reaction

We calculated unexpected stock returns using the market model and used S\&P 500 as the market proxy.

\section{TEST RESULTS}

The test results are presented in Table 4 .

Table 4

Regression Test Results

\begin{tabular}{|c|c|c|c|c|}
\hline Market Cycles & $\underline{\boldsymbol{B}}_{0}$ & t-value & $\underline{\boldsymbol{B}}_{1}$ & t-value \\
\hline Neutral & 1.76 & 8.450 & .157 & .917 \\
\hline Optimistic & 2.033 & 11.118 & .148 & 2.864 \\
\hline Pessimistic & .913 & 4.143 & -.971 & -1.650 \\
\hline
\end{tabular}

Table 4 shows that $\beta_{1}$ is insignificant for the neutral cycle, which indicates that increase in discretionary accruals is not associated with higher unexpected stock returns. These findings provide a support for the hypothesis 1 and suggest that investors detected abnormal changes in discretionary accruals and discounted them in the stock prices. Table 4 also shows that the coefficient is positive and significant for the optimistic cycle indicating that increase in discretionary accruals was associated with higher unexpected stock returns. These findings support hypothesis 2 and indicate that investors did not pay attention to the true nature of earnings changes in the optimistic cycle. For the pessimistic cycle, the coefficient is negative, but weakly significant. This indicates that although the sign of the coefficient presents support for hypothesis 3 , we do not find strong support for this hypothesis.

\section{Industry Effect}

In this section, we focus on optimistic cycle for which we found strong positive association between increase in discretionary accruals and stock returns. We test whether the industry membership was effective. This type of investigation helps to indicate whether industry membership was a significant factor in engaging in managing earnings during the optimistic cycle. The investigation is also beneficial as the degree of optimistic market environment can vary depending on the industry. To test the industry effect, we compute the following metric for each industry:

$$
\overline{D A C_{I N D}}=\sum D A C_{i, I N D} / n_{I N D}
$$

where $\overline{D A C_{I N D}}$ is the mean of discretionary accruals for each industry, $\mathrm{DAC}_{\mathrm{i}, \mathrm{IND}}$ is discretionary accruals for firm I in each industry, and $\mathrm{n}_{\mathrm{IND}}$ is number of the firms in each industry. The test results are presented in table 5 .

Table 5 indicates that the discretionary accruals means are significant for the following four industries: capital goods, construction, consumer goods, and energy (consumer goods is significant at .1 level).The mean, however, is not significant for basic industries and finance. The findings show that earnings management was not observed across industries alike. These findings suggest that market optimism, providing the incentive for earnings management, may exist only in certain industries. 
Table 5

Earnings Management And Industry Membership

\begin{tabular}{|llllll|}
\hline Industry & \multicolumn{1}{c}{ Samples } & $\underline{D A C_{I N D}}$ & $\underline{\text { T-value }}$ & $\underline{\text { Sig. }}$ \\
\cline { 2 - 2 } Basic Industries & 115 & 1.149 & 1.086 & .280 \\
Capital Goods & 385 & .073 & 3.537 & .000 & .001 \\
Construction & 44 & .052 & 3.418 & .071 \\
Consumer Goods & 813 & .178 & 1.810 & .001 \\
Energy & 110 & .137 & 3.413 & .128 \\
Finance & 42 & 8.372 & 1.553 & \\
Total & 1509 & & & & \\
\hline
\end{tabular}

\section{SUMMARY AND CONCLUSION}

This paper presents evidence about the effect of stock market cycles on the association between earnings management and stock price returns. It shows that when the stock market is in its optimistic cycle, it affects investors, who tend to ignore the nature of changes in earnings. In such conditions, investors are more receptive of ambitious business actions done by management, which may results in higher accruals. This situation presents ground for the likelihood of engaging in earnings management. In addition, the market high performance in an optimistic cycle attracts naive investors who may not be able to analyze the nature of changes in EPS and distinguish between discretionary and non-discretionary accruals. Our results provide that one dollar increase in discretionary accruals resulted in fifteen cents increase in stock price return on average in the optimistic market cycle. On the other hand, our results show that investors were able to identify the effect of discretionary accruals on EPS changes in the neutral market environment and discount that effect in the stock prices. The test results proved that there was no association between increase in discretionary accruals and increase in stock prices in the neutral cycle. This could be due to the fact that there is no emotions involved in decision making in this cycle, and fewer naive investors exist in the market. Furthermore, our test results show that investors may react negatively to increase in discretionary accruals in the pessimistic cycle. We found a negative relationship between increase in discretionary accruals and stock prices in the pessimistic cycle. These findings suggest that when the market environment is generally negative, boosting EPS by increasing discretionary accruals will have a negative effect of investors' valuation of stock prices. The test results also prove that the association between increase in discretionary accruals and increase in stock returns was not the same in all investigated industries. It suggests that the optimistic cycle could be driven by factors that affect only certain industries.

This study contributes to the growing literature on the subject of factors limiting firm's ability to engage in earnings management, as well as the effect of market cycle in this process. Furthermore, the results presented in this study may help researchers and financial analysts to understand the true nature of ratios such as P/E (price to EPS) and $\mathrm{P} / \mathrm{B}$ (price to book value) in different market cycles. Our findings suggest that the time series analysis of $\mathrm{P} / \mathrm{E}$ and $\mathrm{P} / \mathrm{B}$ ratios without proper adjustment for the effect of market cycles on discretionary accruals may be biased and misleading.

This study is limited in some aspects. We selected firms that had sufficient data in Compustat files; although our sample is fairly large for statistical analyses, the effects of firms not listed in Compustat or without sufficient data are excluded. We also selected the total of fifteen quarters as optimistic, neutral and pessimistic cycles. Although those quarters reflected dramatic shifts during the selected time period, the effect of larger cycles may not be consistent with our results. Also, we use the data of the U.S. stock markets, which may not represent the effect of market cycles in other courtiers. These limitations present opportunities for future studies to extent research on this topic. In addition, the findings of this paper could be reevaluated using other models presented in the literature (such as industry-based model) for normal accrual estimation. 


\section{REFERENCES}

1. Abarbanell, J. and R. Lehavy. 2003. Biased Forecasts or biased earnings? The Role of Reported Earnings in Explaining Apparent Bias and Over/Under-Reaction in Analysts' Earning Forecast. Journal of Accounting and Economics, 36: 105.

2. Abarbanell, J. and R. Lehavy. 2003. Can Stock Recommendations Predict Earnings Management and Analysts' Earnings Forecast Errors? Journal of Accounting Research, 41: 1-31.

3. Aharony, J., C. J. Lee and T. J. Wong. 2000. Financial Packaging of IPO Firms in China. Journal of Accounting Research, 38: 103-126.

4. Ajinkya, B., S. Bhojraj and P. Sengupta. 2005. The Association Between Outside Directors, Institutional Investors and Properties of Management Earnings Forecast. Journal of Accounting Research, 43: 343.

5. Barton, J. and P. Simko. 2002. The Balance Sheet as an Earnings Management Constraint. The Accounting Review, 77: 1-27.

6. Beaver, W. and E. Engel. 1996. Discretionary Behavior With Respect to Allowances for Loan Losses and the Behavior of Security Prices. Journal of Accounting and Economics, 22: 177.

7. Beneish, M. 1997. Detecting GAAP Violation: Implications for Assessing Earnings Management Among Firms with Extreme Financial Performance. Journal of Accounting and Public Policy, 16: 271.

8. Beneish, M. 1999. The Detection of Earnings Manipulation. Financial Analysis Journal, 55: 24-36.

9. Beneish, M. 1999. A Note on Wiedman's Instructional case: Detecting Earnings Manipulation. Issues in Accounting Education, 14: 369-370.

10. Burgstahler, D. and I. Dichev. 1997. Earnings Management to Avoid Earnings Decreases and Losses. Journal of Accounting and Economics, 24: 99-126.

11. Burgstahler, D. and M. Eames. 1998. Management of Earnings and Analysts Forecasts. Working paper, University of Washington.

12. Cheng, Q. and T. Warfield. 2005. Equity Incentives and Earnings Management. The Accounting Review, 80: 441-476.

13. Dechow, Patricia M., Richard G. Sloan and Amy P. Sweeney. 1995. Detecting Earnings Management. The Accounting Review, 70: 193.

14. DuCharme, Larry L., Paul H. Malatesta, Stephan E. Sefcik. 2004. Earning Management, Stock Issues, and Share Holder Lawsuits. Journal of Financial Economics, 71: 27.

15. Degeorge, F., J. Patel and R. Zeckhauser. 1999. Earnings Management to Exceed Thresholds. The Journal of Business, 72: 1-33.

16. Erickson, M. and S-W. Wang. 1999. Earnings Management by Acquiring Firms in Stock for Stock Merger. Journal of Accounting and Economics, 27: 149-176.

17. Fischer, P. and P. Stocken. 2004. Effect of Investor Speculation on Earning Management. Journal of Accounting Research, 42: 843.

18. Heron, R. and E. Lie. 2002. Operating Performance and the Method of Payment in TakeOver. Journal of Financial and Quantitative Analysis, 37: 137-155.

19. Karamanou, I. and N. Vafeas. 2005. The Association Between Corporate Boards, Audit Committees, and Management Earnings Forecasts: An Empirical Analysis. Journal of Accounting Research, 43: 453.

20. Kasznik, R. 1999. On the Association Between Voluntary Disclosure and Earnings Management. Journal of Accounting Research, 37: 57-81.

21. Leuz, C., D. Nanda and P. Wysocki. 2003. Earnings Management and Investor Protection: an International Comparison. Journal of Financial Economics, 69: 505.

22. Li, Y. and B. McConomy. 2004. Simultaneous Signaling in IPO's via Management Earnings Forecasts and Retained Ownership: An Empirical Analysis of the Substitution Effect. Journal of Accounting, Auditing and Finance, 19: 1.

23. Lacina, M. and K. Karim. 2004. Tests of Market Reaction and Analysts' Forecast Revisions to Disclosure of Improved Management Earnings Expectations: A Case of Concurrent Bad News Management Earnings Forecasts. Review of Quantitative Finance and Accounting, 23: 123.

24. Louis, H. 2004. Earnings Management and the Market Performance of Acquiring Firms. Journal of Financial Economics, 74:121.

25. Marquardt, C. and C. Wiedman. 2004. The Effect of Earning Management on the Value Relevance of Accounting Information. Journal of Business Finance \& Accounting, 31: 297-332. 
26. Marquardt, C. and C. Wiedman. 2004. How are Earnings Managed? An Examination of Specific Accruals. Contemporary Accounting Research, 21: 461-489.

27. Matolcsy, Z. 2000. Executive Cash Compensation and Corporate Performance During Different Economic Cycles. Contemporary Accounting Research, 17: 671-692.

28. McNichols, M., P. Wilson. and D. Linda. 1988. Evidence of Earnings Management from the Provision for Bad Debts; Discussion. Journal of Accounting Research, 26: 1-40.

29. Rangan, S. 1998. Earnings Before Seasoned Equity Offerings: are They Overstated? Journal of Financial Economics, 50: 101-122.

30. Shivakumar, L. 2000. Do Firms Mislead Investors by Overstating Earnings Before Seasoned Equity Offering?.Journal of Accounting and Economics, 29: 339-371.

31. Siew, Hong. T., Ivo Welch and T. J. Wong. 1998. Earnings Management and the Long-Run Market Performance of Initial Public Offerings. The Journal of Finance, 53: 1935.

32. Teoh, S. T., I. Welch and T. J. Wong. 1998. Earnings Management and the Post-Issue Performance of Seasoned Equity Offerings. Journal of Financial Economics, 50: 63-99.

33. Yongtae, K. and S. P. Myung. 2005. Pricing of Seasoned Equity Offers and Earning Management. Journal of Financial and Quantitative Analysis, 40: 435. 
Journal of Business \& Economics Research-August, 2009

Volume 7, Number 8

\section{NOTES}

